\title{
Serum Isocitrate Dehydrogenase Activity in Reye's Syndrome'
}

\author{
Devendra R. Deshmukh, ${ }^{2}$ Thomas C. Shopf, and Ashok P. Sarnaik* \\ Department of Pediatrics, University of Michigan, Ann Arbor, Michigan 48109, and *Children's \\ Hospital of Michigan, Detroit, Michigan 48201
}

Received May 15, 1986

Biochemical and histopathological studies provide evidence of acute mitochondrial insult in Reye's syndrome. These studies suggest that the metabolic abnormalities seen in Reye's syndrome could be due to mitochondrial dysfunction (1). In the liver of Reye's syndrome patients, the activities of all mitochondrial enzymes assayed to date have been decreased, whereas most of the cytoplasmic enzyme activities are normal. The decrease in mitochondrial enzymes could be due to decreased synthesis, increased degradation, inhibition, inactivation, or loss from liver cells into serum and other biological fluids. Our previous studies (2) and those of Holt et al. (3) showed that the activities of ornithine carbamyl transferase (an enzyme found mainly in the liver mitochondria), were elevated in the serum of many Reye's syndrome patients, and maximum elevation was seen in Stage I patients. Recent studies by Holt et al. (3) and from our laboratory (4) showed that the activities of glutamate dehydrogenase (a mitochondrial enzyme) were also elevated in the serum of Reye's syndrome patients. These results suggest that the activities of other mitochondrial enzymes that are known to decrease in the liver of Reye's syndrome patients may appear in the blood. To test this hypothesis we determined the activities of isocitrate dehydrogenase (EC 1.1.1.42) in the plasma of 12 Reye's syndrome patients.

\section{METHODS}

Twelve Reye's syndrome patients admitted to the Children's Hospital of Michigan during 1982-1984 were included in this study. Blood specimens were collected at the time of admission in heparinized tubes and immediately centrifuged at $4^{\circ} \mathrm{C}$ $(5000 \mathrm{~g})$ for $15 \mathrm{~min}$. Plasma was separated and stored at $-70^{\circ} \mathrm{C}$.

Selection of cases was based solely on the availability of stored sera of children who had been diagnosed as having definite or probable Reye's syndrome according to previously described criteria, and for whom pretreatment SGOT, and $\mathrm{S}-\mathrm{NH}_{3}$

\footnotetext{
${ }^{1}$ Supported in part by a grant from the National Institutes of Health, AI 20236-03. D.R.D. is a recipient of the Research career development award from the National Institutes of Health.

2 To whom all correspondence should be addressed at: F7828, Box 0244, C.S. Mott Children's Hospital, University of Michigan, Ann Arbor, MI 48109.
} 
TABLE 1

Serum Isocitrate Dehydrogenase Activity and Clinical Parameters in Reye's Syndrome Patients

\begin{tabular}{cccccccc}
\hline $\begin{array}{c}\text { Age } \\
\text { (years) }\end{array}$ & Sex & Stage & Outcome & $\begin{array}{c}\mathrm{SNH}_{3} \\
\mu \mathrm{g} / \mathrm{dl}\end{array}$ & $\begin{array}{c}\text { SGOT } \\
\text { IU/liter }\end{array}$ & $\begin{array}{c}\text { SOCT } \\
\text { IU/liter }\end{array}$ & $\begin{array}{c}\text { SIDH } \\
\text { IU/liter }\end{array}$ \\
\hline 9 & F & II & S & 200 & 153 & 16.7 & 39.0 \\
5 & F & I & S & 90 & 730 & 73.8 & 33.0 \\
22 & M & IV & S & 140 & 350 & 10.6 & 24.0 \\
12 & F & II & S & 100 & - & 26.6 & 21.5 \\
- & - & II & - & - & - & 122.0 & 32.5 \\
- & - & I & - & - & - & 27.0 & 2.3 \\
10 & F & III & S & 249 & 338 & 18.3 & 6.4 \\
4 & M & II & S & 411 & 324 & 21.0 & 3.9 \\
7 & M & II & - & 180 & 94 & 14.7 & 5.1 \\
13 & F & II & - & 251 & 387 & 18.4 & 21.7 \\
- & - & II & - & - & - & 54.0 & 12.9 \\
- & - & - & - & - & - & 54.0 & 50.4 \\
\hline
\end{tabular}

values were reported for the same day, usually the day of admission, on which the stored samples were collected.

SOCT activities were measured by the method of Cerriotti (5). Standard assays of serum GOT and ammonia were done in the clinical laboratories of the Children's Hospital of Michigan for diagnostic purposes and were taken from the patient records. Stages were those assigned at the time of admission by the attending physicians and are based on the staging criteria described by Lovejoy et al. (6).

Isocitratc dehydrogenase activity in plasma was determined at $25^{\circ} \mathrm{C}$ as described by Bowers (7).

\section{RESULTS}

The activity of isocitrate dehydrogenase was elevated in most of the patients (21.2 $\pm 15.5 \mathrm{IU} /$ liter, mean \pm SEM, range $2-51 \mathrm{IU} /$ liter $)$. Normal range for isocitrate dehydrogenase activity is $0.5-6 \mathrm{IU} /$ liter (see Table 1).

There was no direct correlation between elevated serum isocitrate dehydrogenase activity and other clinical parameters such as serum ammonia, OCT, GOT, or the stages of the disorder.

\section{DISCUSSION}

Although isocitrate dehydrogense is widely distributed in body tissues (8), the enzyme is primarily of liver origin and marked elevations in serum isocitrate dehydrogenase are seen only in diseases involving hepatocellular damage. Our findings show that, similar to ornithine carbamyl transferase and glutamate dehydrogenase, isocitrate dehydrogenase activities were also increased in the serum of Reye's syndrome patients. These results support our hypothesis that the activities of other mitochondrial enzymes known to be decreased in the liver of Reye's syndrome patients may be increased in blood. Additional measurements of OCT, GDH, IDH, and other mitochondrial enzymes in the sera of RS patients are necessary to confirm the hypothesis. Whether the activities of cytoplasmic 
enzymes are increased in the serum of Reye's syndrome patients also remains to be seen.

Because Reye's syndrome is a rare disorder, only a small number of samples was available for this study. Additional serial measurements of various metabolic parameters and other mitochondrial enzymes may help to clarify the relationship, if any, of the elevation of mitochondrial enzymes in serum to the pathogenesis of Reye's syndrome.

\section{SUMMARY}

Serum levels of isocitrate dehydrogenase was determined in 12 Reye's syndrome patients and the enzyme levels were compared with serum ornithine carbamyl phosphate, glutamic oxaloacetic transaminase (aspartate aminotransferase), ammonia, and the stages of the disorder. Isocitrate dehydrogenase was elevated in 8 of the 12 patients and there was no direct correlation between elevated serum isocitrate dehydrogenase level and other clinical parameters.

\section{ACKNOWLEDGMENT}

We thank Dr. Janet Gilsdorf for her comments on the manuscript.

\section{REFERENCES}

1. DeVivo, D. C., Neurology 28, 105 (1978).

2. Deshmukh, D. R., Rittenhouse, J. W., Mason, M., and Baublis, J. V., Enzyme 27, 45 (1982).

3. Holt, J. T., Arvan, D. A., and Mayer, T., Lancet 2, 4 (1983).

4. Deshmukh, D. R., Thomas, P. E., McArthur, B., and Sarnaik, A. P., Enzyme 33, 171 (1985).

5. Cerriotti, G., "Clinical Biochemistry" (R. Curtins, Ed.), Vol. 2, p. 1151, de Gruyther, Berlin, 1978.

6. Lovejoy, F. J., Jr., Smith, A. L., and Bresnan, M. J., Amer. J. Dis. Child. 128, 36 (1974).

7. Bowers, G. N., Jr., Clin. Chem. 5, 509 (1959).

8. Hoffman, W. J., "The Biochemistry of Clinical Medicine," 4th ed., Vol. 61. Yearbook, Chicago, 1970. 